FOOT-AND-MOUTH DISEASE.

Appointment of a Committee of Investigation. T $\mathrm{HE}$ recurrence of this disease in England during the present year has been a source of grave concern to all engaged in agricultural and live-stock industries. It is, however, a matter for congratulation to the Board of Agriculture, and its veterinary department in particular, that the disease has been stamped out again with such a comparatively small loss. There have been eighteen outbreaks this year, with 467 animals affected, an approximate average of 26 animals in each outbreak. This is truly remarkable considering that foot-and-mouth disease is probably the most rapidly contagious of all epizootics.

During the four years immediately preceding the present year, there were five outbreaks with 127 animals affected, each outbreak being suppressed in little more than a week, at a total cost of a few thousand pounds. This has only been possible as the result of early diagnosis and the immediate slaughter of all affected and contact animals. The importance of drastic and immediate action can be well realised by noting some of the latest Continental returns. In Germany during August alone there were 37,737 outm breaks of foot-and-mouth disease; in July 12,385 were recorded in Holland, 4,097 in Belgium, and 16,027 in France, where it has been estimated that the loss will amount to more than fifteen millions sterling.

The new Minister for Agriculture has therefore taken a very wise step in appointing a committee, as announced in Parliament last week, "to inquire into the circumstances of the recent outbreaks of foot-andmouth disease and to consider whether any further measures can be adopted to prevent their recurrence." The committee of twelve is to be presided over by Sir Ailwyn Fellowes, and includes the members of Parliament for South Wilts, St. Patrick's Division of Dublin, Barkston Ash, Carmarthen West, Newmarket, and North Bucks, together with Major E. M. Dunne, Mr. R. Carr, Mr. E. E. Morrison, Mr. E. P. Nunneley, and a member of the Central Chamber of Agriculture. They are to be assisted by the veterinary and administrative officers of the Board.

Of greater importance, however, is the proposal to appoint an expert scientific committee to proceed to India, where the disease is unfortunately very rife, to investigate the special characteristics of the disease, its etiology, the means by which it is contracted and spread, and practicable means of prevention. It is to be hoped that tangible results will be attained, so that we can continue to enjoy the markets of the world for our live-stock, as the result of the freedom of these islands from such animal scourges.

\section{DR. W. SUTHERLAND.}

$\mathrm{I} T$ is with regret that we have observed the report of the sudden death, on October 4, of Dr. William Sutherland, at his residence, Stawell Street, Melbourne, as recorded in The Melbourne Age. Dr. Sutherland was born in Scotland in 1859 . At the age of ten he went with his parents to live in Melbourne. He obtained a Government exhibition, and finished his preliminary education at Wesley College. From there he went to the University, where he took his Master of Arts degree, obtaining the highest honours each year in mathematics. The winning of the Gilchrist scholarship in his final year enabled him, under the terms of the exhibition, to go to London University College. He was then only twenty years of age. Three years later he returned to Australia, having obtained a degree in science.

From that time until his death Dr. Sutherland deNO. 2 I95, VOL. 887 voted himself entirely to original scientific research. $\mathrm{He}$ contributed papers to scientific periodicals in America, England, and on the Continent. His first line of thought led him to inquire into the molecular constitution of matter in its various phases of liquids and solids. Later he devoted attention to the subject of viscosity. His papers, which appeared mainly in The Philosophical Magazine, are well known to the scientific world. They are distinguished by great width of reading in the latest phases of the subjects he treated, combined with very bold speculation always brought into ample comparison with experimental knowledge. His greatest success was the discovery, in 1893, of the relation connecting the viscosity of a gas with the temperature; the result of a very ingenious, though not quite demonstrative, theoretical argument, and amply confirmed by all subsequent work. His writings were copious in all problems connected with molecular physics, whether they concerned laws of attraction between molecules, the nature of emulsion in its physiological ramifications, the application of electrons and of electrochemical ideas to the properties of matter, the molecular structure of water, or many other subjects. His generalisations were, indeed, so numerous that it was often a difficult task to try to estimate their value. Although Dr. Sutherland had thus contributed a large number of papers to various scientific journals, he never published anything in book form. He preferred to devote his energies entirely to original work and research. For a period he discharged the duties of professor of physics at the Melbourne University during a temporary absence of the occupant of the chair; but in the main he preferred freedom and control of his time. His relations with the University staff were cordial and intimate. $\mathrm{He}$ was an examiner at the University and at the College of Pharmacy, and was also connected with the scientific work of the School of Mines.

J. L.

\section{NOTES.}

WE are informed that Dr. Glazebrook, the director of the National Physical Laboratory, who has been seriously ill since the end of September with enteric fever, is now making satisfactory progress. After so long an attack of fever his recovery must necessarily be somewhat slow, and it may yet be some little time before he can be regarded as convalescent; but there is good reason to hope that the recent marked improvement may be maintained.

The case of the Hawke and Olympic collision, which is now before the Admiralty Courts, is directing considerable attention to the influence of passing vessels upon each other, particularly when those vessels are travelling in the same direction at speeds not differing greatiy from each other. Experiments are now being made at the William Froude Tank of the National Physical Laboratory, with models of the Hawke and Olympic, to test whether such an influence was present and acting at the time of the collision. The president of the Admiralty Court and the various counsel paid a visit to the experiment tank on Saturday last and witnessed a large number of experiments with the models. These were of wax, and were towed from the carriage, or bridge, which spans the large waterway of the tank. The general theory of the influence of passing ships upon each other is the outcome of the "stream-line" theory of the late Prof. Rankine; and we hope to give a fuller account of this shortly.

$A_{N}$ earthquake of unusual strength was felt on November 16 at about 9.25 p.m. (Greenwich mean time) in the south of Germany, throughout Switzerland, and in 